\title{
LINGKUNGAN KERJA, BUDAYA ORGANISASI DAN BEBAN KERJA TERHADAP KINERJA PEGAWAI SMP ISLAM TERPADU PERMATA HATI BANJARNEGARA
}

\author{
Siti Maesaroh ${ }^{1}$; Ulfa Marselina ${ }^{2}$ \\ STIE Tamansiswa Banjarnegara J1. Mayjend Panjaitan No.29 Banjarnegara \\ Email : sitimaesaroh@stietsbanjarnegara.ac.id ${ }^{1}$; ulfamarcelina69@gmail.com² $^{2}$
}

\begin{abstract}
Every company needs an organization. Important factors that can affect the performance of these employees can be a work problem, work environment and work culture of the workplace. This study aims to determine whether the work environment, cultural organization, and workload are related to the performance of employees at SMP IT Permata Hati Banjarnegara. This study uses quantitative by collecting primary data obtained by requesting questionnaires to employees. The population data used is the population of individuals and teachers of SMP IT Permata Hati Banjarnegara numbering 40 people with the sample used is a saturated sample so that the total number of research samples is there. The results showed a positive and significant work environment on the performance of SMP IT Permata Hati Banjarnegara. Organizational Culture does not have a positive and significant effect on the performance of SMP IT Permata Hati Banjarnegara. Positive and significant workload on the performance of employees at SMP IT Permata Hati Banjarnegara. The work environment, organizational culture and workload have a significant influence on employee performance.
\end{abstract}

Keywords: Work Environment, Organizational Culture, Workload and Employee Performance

\section{PENDAHULUAN}

\section{Latar Belakang}

Setiap perusahaan atau organisasi memerlukan sumberdaya untuk mencapai tujuannya. Sumber daya yang dibutuhkan itu, salah satunya adalah sumberdaya manusia. Menurut Beardwell dan Claydon, dalam Agripa (2013)
Manajemen sumber daya manusia didefinisikan sebagai "a managerial perspective which argues the need to establish an integrated series of personnel policies to support organization strategy". Sumber daya manusia (SDM) harus dikelola dengan baik agar tujuan perusahaan dapat dimaksimalkan. Manajemen sumber daya manusia 
mempunyai beberapa tujuan, salah satunya adalah tujuan organisasi yaitu untuk mencapai apa yang menjadi tujuan perusahaan dan juga untuk mencapai tujuan pribadi karyawan. Dalam hal ini manajemen sumber daya manusianya harus dapat disinergikan dengan tujuantujuan perusahaan.

Mengingat pentingnya sumber daya manusia (SDM) yang menjadi faktor keberhasilan perusahaan dalam mencapai tujuannya, perusahaan tidak bisa terlepas dari peran tenaga kerja yang baik dan berkualitas. Sehingga dalam rangka pencapaian tujuan perusahaan, diperlukan adanya peningkatan kinerja karyawan.

Dessler dalam Agripa (2013) berpendapat bahwa kinerja Karyawan adalah prestasi aktual karyawan dibandingkan dengan prestasi yang diharapkan dari karyawan. Prestasi kerja yang diharapkan adalah prestasi standar yang disusun sebagai acuan sehingga dapat melihat kinerja karyawan sesuai dengan posisinya dibandingkan dengan standar yang dibuat. Selain itu dapat juga dilihat kinerja dari karyawan tersebut terhadap karyawan lainnya.

Ada beberapa hal yang bisa dilakukan perusahaan untuk dapat memengaruhi kinerja karyawan yaitu diantaranya lingkungan kerja, budaya organisasi dan beban kerja yang dihadapi oleh para karyawan. Lingkungan kerja yang dimaksud adalah segala sesuatu yang ada disekitar para pekerja yang dapat mempengaruhi dirinya dalam menjalankan tugas-tugas yang dibebankan. Secara garis besar, lingkungan kerja terbagi menjadi dua, yaitu lingkungan kerja fisik dan lingkungan kerja nonfisik.

Menurut Sedarmayanti dalam Pratama (2019) lingkungan kerja fisik adalah semua keadaan berbentuk fisik yang terdapat di sekitar tempat kerja yang dapat mempengaruhi karyawan baik secara langsung maupun secara tidak langsung.

Sementara itu lingkungan kerja non fisik menurut Sedarmayanti (2011) adalah semua keadaan yang terjadi yang berkaitan dengan hubungan kerja, baik hubungan dengan atasan maupun hubungan sesama rekan kerja, ataupun hubungan dengan bawahan. Kondisi seperti inilah yang selanjutnya menciptakan antusiasme untuk bersatu dalam organisasi perusahaan untuk mencapai tujuan.

Selanjutnya faktor penting yang dapat mempengaruhi kinerja karyawan ialah beban kerja. Menurut Munandar (2001:383) mendefinisikan beban kerja adalah suatu kondisi dari pekerjaan dengan uraian tugasnya yang harus 
diselesaikan pada batas waktu tertentu. Dapat disimpulkan bahwa beban kerja merupakan tanggung jawab yang diberikan atasan dan harus diselesaikan sesuai waktu yang ditentukan demi tercapainya tujuan. Hal ini tentu akan berdampak pada kinerja karyawan yang buruk jika beban kerja yang diberikan tidak ideal atau proporsional.

Selain beban kerja terdapat faktor lain yang dapat diperhatikan perusahaan yaitu budaya organisasi yang memiliki peran di dalam kelangsungan hidup bagi sumber daya manusia pada suatu perusahaan. Dimana ketika anggota organisasi berada di dalam suatu perusahaan, maka disitulah kelangsungan hidup karyawan selama ia bekerja. Budaya organisasi adalah nilai, prinsip, tradisi, dan sikap yang mempengaruhi cara bertindak anggota organisasi menurut Robbins (2012). Adanya pengaruh budaya organisasi terhadap kinerja karyawan ini didukung oleh penelitian yang dilakukan oleh Syauta, et al (2012) yang berjudul "The influence of organizational culture, organizational commitment to job satisfaction and employee performance (study at Munical Waterworks of Jayapura, Papua Indonesia)" mengatakan bahwa budaya organisasi dapat mempengaruhi kinerja karyawan, adapun penelitian lain yang sependapat oleh peneliti sebelumnya didalam penelitian Hakim (2015) yang berjudul "Effect of Organizational Culture, Organizational Commitment to Performance: Study In Hospital Of District South Konawe Of Southeast Sulawesi." Dari penelitian terdahulu dapat di katakan bahwa budaya organisasi berpengaruh terhadap kinerja karyawan.

Sekolah Menengah Pertama Islam Terpadu (SMP IT) Permata Hati Banjarnegara adalah suatu organisasi berbentuk yayasan yang mengemban misi pelayanan kepada masyarakat melalui bidang sosial dan pendidikan Berbasis nilai Islam. SMP IT Permata Hati memiliki Visi untuk melahirkan para generasi bangsa yang berkarakter Qur'ani, Cerdas, Mandiri dan Bersaing. Oleh karena itu SMP IT dituntut untuk memiliki kinerja yang baik dari sumber daya manusianya atau guru. Guru merupakan salah satu aset yang paling berharga yang dimiliki oleh suatu organisasi, karena manusia satu-satunya sumber daya yang dapat menggerakkan sumber daya lainnya. Dengan demikian, unsur sumber daya manusia atau guru merupakan faktor kunci yang harus dipertahankan suatu organisasi sejalan dengan tuntutan yang senantiasa dihadapi organisasi untuk mencapai tujuan yang ada. 
Faktor-faktor yang telah diuraikan sebelumnya harus diperhatikan oleh organisasi dalam hal ini SMP IT Banjarnegara untuk menghadapi persaingan yang ketat didalam dunia pendidikan sehingga dapat melahirkan generasi yang berguna bagi bangsa. SMP IT yang telah berdiri sejak tahun 2011 terus melakukan berbagai upaya dalam meningkatkan kualitas sumber daya manusianya baik bagi tenaga pendidik dan non pendidik. Hanya saja dari hasil wawancara pra survey yang peneliti lakukan dapat disebutkan bahwa masih terdapat guru yang memiliki kinerja yang belum maksimal (Wawancara Kepala Sekolah, 2020). Hal ini dapat dilihat dari masih terdapat beberapa tenaga pendidik maupun staff non pendidik seperti penjaga asrama dan keamanan yang masih terlambat datang ke sekolah. Selain itu peneliti juga mewawancarai beberapa guru yang ada di SMP IT yang menjelaskan bahwa ruang guru yang sempit menyulitkan dalam melakukan pekerjaan. Hal ini dilihat dari kebisingan yang terjadi di ruang guru dan tata ruang yang tidak rapi sehingga mengganggu kenyamanan dalam melakukan pekerjaan. Selain itu tak jarang terkadang para guru diwajibkan untuk mengikuti kegiatan keagamaan di setiap minggunya yang menghabiskan waktu para tenaga kerja baik pendidik dan non pendidik hal ini menjadi beban tambahan bagi para tenaga kerja.

Tabel 1. 1

Data Kinerja Pegawai SMPIT Permata Hati Banjarnegara Tahun 2014 dan 2019

\begin{tabular}{|l|l|l|l|l|l|}
\hline \multirow{2}{*}{ No } & \multirow{2}{*}{ Jabatan } & \multicolumn{2}{|c|}{2014} & \multicolumn{2}{c|}{2019} \\
\cline { 3 - 6 } & & & & & \\
& & & & & \\
\hline 1 & Kersentase & Keterangan & Persentase & Keterangan \\
\hline 2 & Kepala Bidang & $74 \%$ & Baik & $71 \%$ & Baik \\
\hline 3 & Guru/Pengajar & $79 \%$ & Sangat Baik & $74 \%$ & Baik \\
\hline 4 & Staff/Karyawan & $63 \%$ & Baik & $70 \%$ & Baik \\
\hline 5 & Keamanan & $71 \%$ & Baik & $75 \%$ & Baik \\
\hline
\end{tabular}

Sumber: Subbag Manajemen Informasi SMPIT Permata Hati Banjarnegara

Tabel 1.1 di atas menjelaskan kinerja para pegawai dari SMP IT Permata Hati Banjarnegara pada penilaian tahun
2014 dan 2019. Penilaian kinerja pada tiap pegawai ini berdasarkan beberapa komponen seperti; 1) orientasi pelayanan, 
2) integritas, 3) komitmen, 4) disiplin, 5)

Kerjasama, 6) kepemimpinan.

Berdasarkan output penilaian akhir pada tahun 2014 dan 2019 dapat dilihat terjadi penurunan secara umum terhadap kinerja kepala bidang dan guru pengajar walaupun secara kategori penilaian masih di kategori Baik. Hal ini tentu perlu mendapatkan perhatian untuk mengetahui penurunan kinerja tersebut. Guru dan kepala bidang merupakan salah satu posisi vital dalam mencapai keberhasilan peserta didik yang telah ditetapkan.

Penelitian ini akan mengkaji bagaimana pengaruh lingkungan kerja, budaya organisasi dan beban kerja terhadap kinerja pegawai SMP IT Permata Hati Banjarnegara. Dan bagi sebuah organisasi atau perusahaan yang berusaha agar apa yang mereka tawarkan dapat diterima oleh masyarakat atau target konsumennya tentu saja kinerja pegawai menjadi suatu hal yang penting bagi sebuah perusahaan.

Adapun beberapa penelitian terdahulu terkait kajian kinerja karyawan pernah dilakukan oleh Yasa dan Utama (2014) dengan judul pengaruh kompensasi dan lingkungan kerja terhadap kepuasan kerja dan kinerja karyawan pada Karma Jibaran. Hasil penelitian menunjukan bahwa secara langsung positif dan signifikan kinerja dipengaruhi oleh lingkungan kerja.

Sementara itu penelitian yang dilakukan oleh Arianto (2013) dengan judul penelitian pengaruh kedisiplinan, lingkungan kerja dan budaya kerja terhadap kinerja tenaga pengajar. Hasil penelitian menunjukan bahwa Lingkungan kerja tidak memiliki pengaruh (tidak signifikan) terhadap kinerja tenaga pengajar di Yayasan Pendidikan Luar Biasa Kabupaten Demak.

Selain itu penelitian yang dilakukan oleh Taurisa dan Ratnawati (2012) dengan judul Analisis Pengaruh Budaya Organisasi Kerjga Terhadap Komitmen Organisasional Dalam Meningktakan Kinerja Karyawan Studi Pada PT. Sido Muncul Kaligawe Semarang. Hasil Penelitian menunjukan bahwa budaya organisasi berpengaruh terhadap kinerja pegawai. Berbeda dengan hasil penelitian yang dilakukan oleh Trisnaningsih (2007) yang menunjukan bahwa budaya organisasi tidak memiliki pengaruh yang signifikan terhadap kinerja auditor.

Penelitian lainnya yang dilakukan oleh Muhammad, Adolfina dan Lumintang (2016) dengan judul penelitian Pengaruh Lingkungan Kerja, Kompensasi dan Beban Kerja Terhadap Kinerja 
Karyawan Pada Dinas Pendapatan Daerah

Kota Manado. Menunjukan Hasil bahwa

Beban kerja berpengaruh positif dan signifikan terhadap Kinerja Karyawan. Sedangkan hasil penelitian yang dilakukan oleh Agripa (2013) menunjukan hasil bahwa Beban Kerja tidak berpengaruh terhadap kinerja karyawan.

Berdasarkan pada uraian tersebut di atas, maka peneliti ingin mengajukan sebuah penelitian dengan judul "Pengaruh Lingkungan Kerja, Budaya Organisasi dan Beban Kerja Terhadap Kinerja Pegawai SMP IT Permata Hati Banjarnegara".

\section{RUMUSAN MASALAH}

1. Apakah ada pengaruh lingkungan kerja terhadap kinerja pegawai SMP IT Permata Hati Banjarnegara?

2. Apakah ada pengaruh budaya organisasi terhadap kinerja pegawai SMP IT Permata Hati Banjarnegara?

3. Apakah ada pengaruh beban kerja terhadap kinerja pegawai SMP IT Permata Hati Banjarnegara?

4. Apakah ada pengaruh lingkungan kerja, budaya organisasi dan beban kerja terhadap kinerja pegawai SMP IT Permata Hati Banjarnegara?

\section{METODE PENELITIAN}

\section{Lokasi Penelitan}

Lokasi penelitian dilakukan di SMP IT Permata Hati Banjarnegara, di Jalan Abu Bakar No. 11 Petambakan, Kecamatan Madukara, Kabupaten Banjarnegara.

\section{Jenis Penelitian}

Penelitian ini menggunakan data kuantitatif.

\section{Variabel Penelitian}

A. Variabel Independent: Lingkungan Kerja $\left(\mathrm{X}_{1}\right)$, Budaya Organisasi $\left(\mathrm{X}_{2}\right)$, Beban Kerja (X3)

B. Variabel Dependent: Kinerja Pegawai (Y)

\section{Definisi Konsep dan Definisi Operasional Variabel}

\section{a. Lingkungan Kerja}

Definisi konsep: lingkungan kerja adalah keseluruhan alat perkakas dan bahan yang dihadapi, lingkungan sekitarnya dimana seseorang bekerja, metode kerjanya, serta pengaturan kerjanya baik sebagai perseorangan maupun sebagai kelompok. Sedarmayanti (2011)

Definisi operasional: Lingkungan kerja fisik adalah semua keadaan berbentuk fisik yang terdapat di sekitar tempat kerja. Lingkungan kerja non fisik adalah semua keadaan yang terjadi berkaitan dengan 
hubungan kerja baik dengan atasan maupun sesama rekan kerja.

Indikator: Kelengkapan peralatan kerja, Kebersihan ruang kerja, Layout ruangan, Pengawasan, Suasana kerja, Hubungan antara rekan kerja dan Hubungan pimpinan dan bawahan

\section{b. Budaya Organisasi}

Definisi konsep: Budaya organisasi merupakan norma-norma dan nilai-nilai yang mengarahkan perilaku anggota organisasi. Setiap anggota organisasi akan berperilaku sesuai dengan budaya yang berlaku agar diterima oleh lingkungannya (Luthans 2011).

Definisi Operasional: Budaya organisasi merupakan suatu sistem berupa sikap, nilai, norma perilaku, bahasa yang dibentuk dan dikembangkan kepada anggota organisasi sebagai kepribadian organisasi.

Indikator: Aturan Perilaku, Norma, Nilai Dominan, Filosofi, Aturan, Iklim Organisasi

\section{c. Beban Kerja}

Definisi konsep: Beban kerja karyawan sudah ditentukan oleh perusahaan menggunakan standar kerja menurut jenis pekerjaannya (Mangkuprawira dalam Anggit, 2014).

Definisi operasional: Beban kerja merupakan keadaan dimana pekerja dihadapkan pada tugas yang harus diselesaikan pada waktu tertentu baik

Indikator: Target Yang Harus Dicapai, Kondisi Pekerjaan, dan Standar Pekerjaan.

\section{d. Kinerja pegawai}

Definisi konsep: kinerja adalah suatu hasil kerja yang dicapai seseorang dalam melaksanakan tugas tugas yang dibebankan kepadanya yang didasarkan atas kecakapan, pengalaman dan kesungguhan serta waktu (Bastian, 2013).

Definisi operasional: kinerja merupakan pola perilaku dan tindakan dari para karyawan yang relevan dengan tujuan organisasi

Indikator: Kesesuaian hasil kerja dengan tujuan yang diharapkan, Kuantitas hasil kerja yang mampu dihasilkan, Ketepatan waktu penyelesaian pekerjaan, Kemampuan menggunakan fasilitas kerja secara efisien, Kemampuan melaksanakan pekerjaan secara mandiri dan Tanggungjawab dalam melaksanakan pekerjaan

\section{Populasi Sampel dan Teknik Sampling}

\section{a. Populasi Penelitian}

Populasi individu pegawai dan guru SMP IT Permata Hati Banjarnegara yang berjumlah 40 orang

\section{b. Sampel}


Karena jumlah populasi yang relatif kecil,

Sehingga sampel yang digunakan pada penelitian ini berjumlah 40 orang.

\section{c. Teknik Sampling}

Teknik pengambilan sampel yang digunakan yaitu sampling jenuh (sensus).

\section{Teknik Analisis Data}

Adapun teknik analisis data yang digunakan dalam penelitian ini adalah:

a. Uji Instrumen, terdiri dari :

1. Uji Validitas

2. Uji Reabilitas

b. Uji Asumsi Klasik, terdiri dari :

1. Uji Normalitas

2. Uji Multikolinearitas

3. Uji Heteroskedastisitas

c. Teknik Analisis Data dan Uji Hipotesis, terdiri dari :

1. Regresi Berganda

2. Uji Hipotesis
a. Uji t
b. Uji F
c. Uji Koefiseien Determinasi

\section{HASIL DAN PEMBAHASAN}

\section{Uji Instrumen}

\section{a. Uji Validitas}

Hasil Uji Validitas instrumen penelitian

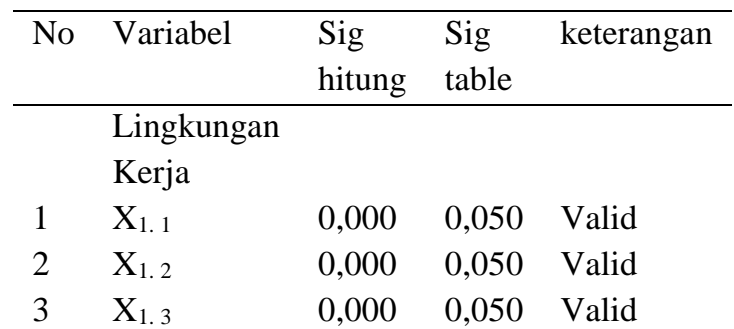

Vol. 12, No. 1, Januari 2021, Halaman 38-54

\begin{tabular}{lllll}
4 & $X_{1.4}$ & 0,000 & 0,050 & Valid \\
5 & $X_{1.5}$ & 0,000 & 0,050 & Valid \\
6 & $X_{1.6}$ & 0,000 & 0,050 & Valid \\
7 & $X_{1.7}$ & 0,000 & 0,050 & Valid \\
8 & $X_{1.8}$ & 0,000 & 0,050 & Valid \\
9 & $X_{1.9}$ & 0,000 & 0,050 & Valid \\
\hline & Budaya & & & \\
& Organisasi & & & \\
1 & $X_{2.1}$ & 0,000 & 0,050 & Valid \\
2 & $X_{2.2}$ & 0,000 & 0,050 & Valid \\
3 & $X_{2.3}$ & 0,000 & 0,050 & Valid \\
4 & $X_{2.4}$ & 0,000 & 0,050 & Valid \\
5 & $X_{2.5}$ & 0,000 & 0,050 & Valid \\
6 & $X_{2.6}$ & 0,000 & 0,050 & Valid \\
\hline & Beban & & & \\
& Kerja & & & \\
1 & $X_{3.1}$ & 0,000 & 0,050 & Valid \\
2 & $X_{3.2}$ & 0,000 & 0,050 & Valid \\
3 & $X_{3.3}$ & 0,000 & 0,050 & Valid \\
4 & $X_{3.4}$ & 0,000 & 0,050 & Valid \\
5 & $X_{3.5}$ & 0,000 & 0,050 & Valid \\
6 & $X_{3.6}$ & 0,000 & 0,050 & Valid \\
7 & $X_{3.7}$ & 0,000 & 0,050 & Valid \\
7 & $X_{3.8}$ & 0,000 & 0,050 & Valid \\
7 & $X_{3.9}$ & 0,000 & 0,050 & Valid \\
\hline & $K_{1.9}$ & & &
\end{tabular}

\begin{tabular}{lllll}
\hline \multicolumn{5}{c}{ Kinerja } \\
& pegawai & & & \\
1 & $Y_{.1}$ & 0,000 & 0,050 & Valid \\
2 & $Y_{.2}$ & 0,000 & 0,050 & Valid \\
3 & $Y_{.3}$ & 0,000 & 0,050 & Valid \\
4 & $Y_{.4}$ & 0,000 & 0,050 & Valid \\
5 & $Y_{.5}$ & 0,000 & 0,050 & Valid \\
6 & $Y_{.6}$ & 0,000 & 0,050 & Valid \\
7 & $Y_{.7}$ & 0,000 & 0,050 & Valid \\
8 & Y.8 & 0,000 & 0,050 & Valid \\
9 & Y.9 & 0,000 & 0,050 & Valid \\
10 & Y.10 & 0,000 & 0,050 & Valid \\
\hline \multicolumn{5}{l}{ Sumber: Data Primer yang Diolah 2020 }
\end{tabular}

Tabel di atas menunjukan bahwa semua indikator untuk mengukur variabelvariabel dalam penelitian ini mempunyai nilai sign. $<0,05$, sehingga semua indikator valid dan dapat digunakan sebagai alat ukur dalam penelitian ini.

\section{b. Uji Reabilitas}

Hasil Uji Reliabilitas 


\begin{tabular}{llll}
\hline Variabel & $\begin{array}{l}\text { Cron } \\
\text { Alpha }\end{array}$ & $\begin{array}{l}\text { Batas } \\
\text { Reabilitas }\end{array}$ & Keterangan \\
\hline $\begin{array}{l}\text { Lingkunga } \\
\text { n Kerja }\end{array}$ & 0,866 & 0,600 & Reliabel \\
$\begin{array}{l}\text { Budaya } \\
\text { Organisasi }\end{array}$ & 0,825 & 0,600 & Reliabel \\
$\begin{array}{l}\text { Beban } \\
\text { Kerja }\end{array}$ & 0,931 & 0,600 & Reliabel \\
$\begin{array}{l}\text { Kinerja } \\
\text { pegawai }\end{array}$ & 0,896 & 0,600 & Reliabel \\
\hline
\end{tabular}

Sumber: Hasil Output SPSS

Hasil pengujian pada tabel menunjukkan bahwa nilai koefisien Alpha dari variabel - variabel yang diteliti memiliki nilai Cronbach Alpha $>0,600$. Dengan demikian, dapat disimpulkan alat ukur yang digunakan dalam penelitian ini reliabel

\section{Uji Asumsi Klasik}

\section{a. Uji Normalitas}

\begin{tabular}{|l|l|r|}
\hline \multicolumn{2}{|l|}{} & $\begin{array}{c}\text { Standardized } \\
\text { Residual }\end{array}$ \\
\hline N & Mean \\
\hline Normal Parameters & \\
\cline { 2 - 3 } & Std. Deviation &, 0000000 \\
\hline Most Extreme & Absolute &, 136 \\
\cline { 2 - 3 } & Positive &, 104 \\
\cline { 2 - 3 } & Negative &,- 136 \\
\hline Test Statistic & &, 136 \\
\hline Asymp. Sig. (2-tailed) & &, $060^{c}$ \\
\hline
\end{tabular}

Sumber: Hasil Output SPSS

Tabel diatas menunjukkan hasil uji

Kolmogorov-Smirnov Asymp sig hitung sebesar $0,060>0,050$ maka dapat diketahui data dalam penelitian ini berdistribusi normal.

\section{b. Uji Multikolinearitas}

\begin{tabular}{lll}
\hline \multirow{2}{*}{ Model } & \multicolumn{2}{l}{ Collinearity Statistics } \\
\cline { 2 - 3 } & Tolerance VIF \\
\hline 1 (Constant) & & \\
\hline Lingkungan Kerja & .766 & 1.305 \\
\hline Budaya Organisasi & .714 & 1.401 \\
\hline Beban Kerja & .911 & 1.098
\end{tabular}

a. Dependent Variable: Kinerja

Karyawa_Y

Sumber: Hasil Output SPSS

Berdasarkan hasil perhitungan ini tolerance hitung Lingkungan Kerja $(0,766)$, Budaya Organisasi $(0,714)$ dan Beban Kerja $(0,911)>0,100$ (menunjukkan tidak ada variabel independen yang memiliki nilai tolerance kurang dari 0,100.

Berdasarkan tabel di atas nilai variabel Lingkungan Kerja mempunyai nilai VIF sebesar 1.305. Sementara Budaya Organisasi mempunyai nilai VIF sebesar 1.401 dan variabel Beban Kerja mempunyai VIF sebesar 1.098 yang berarti < 10. jika dilihat dari nilai tolerance dan nilai VIF di atas maka dapat disimpulkan semua variabel tidak terjadi gejala multikolinieritas.

\section{Uji Heteroskedastisitas}




\begin{tabular}{|c|c|c|c|c|c|c|}
\hline \multirow{2}{*}{\multicolumn{2}{|c|}{ Model }} & \multicolumn{2}{|c|}{$\begin{array}{c}\text { Unstandardiz } \\
\text { ed } \\
\text { Coefficients }\end{array}$} & \multirow{2}{*}{$\begin{array}{c}\begin{array}{c}\text { Standa } \\
\text { rdized } \\
\text { Coeffic } \\
\text { ients }\end{array} \\
\text { Beta }\end{array}$} & \multirow[b]{2}{*}{$\mathrm{t}$} & \multirow[b]{2}{*}{ Sig. } \\
\hline & & B & Error & & & \\
\hline \multirow[t]{4}{*}{1} & (Constant) & $-1,115$ & $\begin{array}{r}6,90 \\
3\end{array}$ & &,- 161 & ,873 \\
\hline & $\begin{array}{l}\text { Lingkungan } \\
\text { Kerja }\end{array}$ &,- 015 & ,073 &,- 037 &,- 204 & ,839 \\
\hline & $\begin{array}{l}\text { Budaya } \\
\text { Organisasi }\end{array}$ & ,010 & , 181 & 011 & 057 & ,955 \\
\hline & Beban Kerja & , 103 & ,058 & ,296 & $\begin{array}{r}1,77 \\
1\end{array}$ & ,085 \\
\hline
\end{tabular}

Berdasarkan tabel 4.4 terlihat di atas variabel lingkungan kerja memiliki signifikansi sebesar 0,839 . Variabel Budaya Organisasi memiliki signifikansi sebesar 0,955. Sedangkan beban kerja memiliki signifikansi sebesar $0,085>$ 0,05 . Sehingga data yang dalam penelitian ini tidak mengandung Heteroskedastisitas.

Teknik Analisis Data dan Uji Hipotesis

\section{a. Regresi Berganda dan Uji t}

\begin{tabular}{|l|c|c|c|c|c|}
\hline \multirow{2}{*}{ Model } & \multicolumn{2}{|c|}{$\begin{array}{c}\text { Unstandardized } \\
\text { Coefficients }\end{array}$} & $\begin{array}{c}\text { Standardized } \\
\text { Coefficients }\end{array}$ & $\mathrm{t}$ & Sig. \\
\cline { 2 - 6 } & $\mathrm{B}$ & Std. Error & Beta & & \\
\hline $1 \quad$ (Constant) & 25,822 & 10,295 & & 2,508 &, 017 \\
$\begin{array}{l}\text { Lingkungan } \\
\text { Kerja }\end{array}$ & 0,555 & 0,109 &, 688 & 5,097 &, 000 \\
$\begin{array}{l}\text { Budaya } \\
\text { Organisasi }\end{array}$ & 0,113 & 0,269 &, 059 &, 420 &, 677 \\
Beban Kerja & $-0,242$ & 0,087 &,- 344 & $-2,775$ &, 009 \\
\hline
\end{tabular}

a. Dependent Variable: Total_Y
1. Pengaruh Lingkungan Kerja Terhadap Kinerja Pegawai SMP IT Permata Hati Banjarnegara

Dari tabel diatas dapat diketahui bahwa $t_{\text {hitung }} 5.097>t_{\text {tabel }} 2.4315$ Maka Ha diterima dan Ho ditolak. Dilihat dari nilai signifikansi sebesar $0,000<0,05$. Koefisiensi regresi variabel lingkungan kerja mempunyai nilai yang positif. Hal berarti secara parsial, lingkungan kerja berpengaruh positif dan signifikan terhadap kinerja pegawai SMP IT Permata Hati Banjarnegara. Dengan demikian dapat disimpulkan bahwa Ha diterima dan Ho ditolak. Sehingga, hipotesis yang berbunyi terdapat pengaruh lingkungan kerja terhadap kinerja pegawai SMP IT Permata Hati Banjarnegara diterima.

$\mathrm{H}_{1}$ : lingkungan kerja berpengaruh positif dan signifikan terhadap kinerja pegawai SMP IT Permata Hati Banjarnegara

\section{Pengaruh Budaya Organisasi}

\section{Terhadap Kinerja Pegawai SMP IT}

\section{Permata Hati Banjarnegara}

Variabel budaya organisasi memiliki nilai $t_{\text {hitung }} 0.420<\mathrm{t}_{\text {tabel }} 2.4315$ Maka Ha ditolak dan Ho diterima. Dilihat dari nilai signifikansi sebesar 0,677> 0,05 . Koefisiensi regresi variabel budaya organisasi mempunyai nilai yang positif. Hal ini berarti secara parsial, budaya 
organisasi tidak berpengaruh positif dan signifikan terhadap kinerja pegawai SMP IT Permata Hati Banjarnegara. Dengan demikian dapat disimpulkan bahwa $\mathrm{Ha}$ ditolak dan Ho diterima

$\mathrm{H}_{2}$ : Budaya Organisasi berpengaruh positif dan tidak signifikan terhadap kinerja pegawai SMP IT Permata Hati Banjarnegara

\section{Pengaruh Beban Kerja Terhadap} Kinerja Pegawai SMP IT Permata Hati

\section{Banjarnegara}

Variabel beban kerja memiliki nilai thitung $-2,775>\mathrm{t}_{\text {tabel }} 2.4315 \mathrm{Maka} \mathrm{Ha}$ diterima dan Ho ditolak. Dilihat dari nilai signifikansi sebesar $0,009<0,05$. Koefisiensi regresi variabel beban kerja mempunyai nilai yang negatif. Hal ini berarti secara parsial, beban kerja berpengaruh negatif dan signifikan terhadap kinerja pegawai SMP IT Permata Hati Banjarnegara. Dengan demikian dapat disimpulkan bahwa Ha diterima dan Ho ditolak.

$\mathrm{H}_{3}$ : beban kerja berpengaruh negatif dan signifikan terhadap kinerja Pegawai SMP IT Permata Hati Banjarnegara

\section{Uji F}

\begin{tabular}{|l|l|r|r|r|r|l|}
\hline \multicolumn{2}{|l|}{} & $\begin{array}{c}\text { Sum of } \\
\text { Squar } \\
\text { es }\end{array}$ & df & $\begin{array}{c}\text { Mean } \\
\text { Square }\end{array}$ & $\mathrm{F}$ & Sig. \\
\hline 1 & $\begin{array}{l}\text { Regressi } \\
\text { on }\end{array}$ & $\begin{array}{r}375,12 \\
\text { on }\end{array}$ & 3 & 125,040 & 11,8 &, $000^{\mathrm{b}}$ \\
& Residual & 379,28 & 36 & 10,536 & & \\
& 0 & & & & \\
\cline { 2 - 7 } & Total & 754,40 & 39 & & & \\
& 0 & & & & \\
\hline
\end{tabular}

Pengaruh lingkungan kerja, budaya organisasi dan beban kerja terhadap kinerja pegawai.

Tabel hasi uji $\mathrm{F}$ diatas menunjukkan bahwa $F_{\text {hitung diperoleh sebesar } 11.868>}$ $F_{\text {table }}$ 2,86 dengan tingkat signifikan 0,000. Karena tingkat signifikan $<0,05$ maka dapat dikatakan lingkungan kerja, budaya organisasi dan beban kerja berpengaruh secara simultan dan signifikan terhadap kinerja pegawai SMP IT Permata Hati.

$\mathrm{H}_{4}$ : Lingkungan kerja, Budaya Organisasi, dan Beban kerja berpengaruh secara simultan dan signifikan terhadap kinerja pegawai SMP IT Permata Hati Banjarnegara.

\section{Uji Koefisien Determinasi $\left(\mathbf{R}^{2}\right)$}

Model Summary

\begin{tabular}{|c|c|c|c|c|}
\hline Model & $\mathbf{R}$ & $\begin{array}{c}\text { R } \\
\text { Squar } \\
\text { e }\end{array}$ & $\begin{array}{c}\text { Adjusted } \\
\text { R } \\
\text { Square }\end{array}$ & $\begin{array}{c}\text { Std. } \\
\text { Error } \\
\text { of the } \\
\text { Estim } \\
\text { ate }\end{array}$ \\
\hline 1 & ,705a & ,497 & ,455 & 3,246 \\
\hline
\end{tabular}


Berdasarkan tabel diatas, diperoleh nilai $R$ Square sebesar 0,497 $(49,7 \%)$. Hal tersebut menunjukkan bahwa devisiasi perubahan variabel independen (lingkungan kerja, budaya organisasi, beban kerja) dalam menjelaskan besarnya devisiasi perubahan terhadap variabel dependen (Kinerja Pegawai) adalah sebesar 49,7\%. Sedangkan sisanya sebesar $50,3 \%$ dipengaruhi oleh variabel lain yang tidak termasuk dalam penelitian ini.

\section{PEMBAHASAN}

Pengaruh Lingkungan Kerja Terhadap Kinerja Pegawai SMP IT Permata Hati

\section{Banjarnegara}

Hasil penelitian menunjukan bahwa sesuai dengan hipotesis pertama $\left(\mathrm{H}_{1}\right)$ yang dirumuskan dimana lingkungan kerja berpengaruh terhadap kinerja pegawai. Lingkungan kerja yang baik dapat meningkatkan kinerja kerja yang positif bagi pegawai. Kinerja yang dimiliki para pegawai baik pendidik maupun non pendidik di SMP IT Permata Hati diantaranya pegawai mampu menyelesaikan tugas kerja sesuai dengan target yang ditentukan, tidak pernah menunda pekerjaan, dan selalu hadir tepat waktu.

Hasil penelitian ini juga senada dengan penelitian yang dilakukan oleh Syofyan (2013) yang mengemukakan bahwa terdapat pengaruh lingkungan kerja terhadap kinerja pegawai Bappeda. Selain itu Robbins (2012) juga menjelaskan bahwa para pegawai menaruh perhatian yang besar terhadap lingkungan kerja mereka, baik dari segi kenyamanan pribadi maupun kemudahan melakukan pekerjaan dengan baik. Menurut Sutrisno (2010) lingkungan kerja adalah keseluruhan sarana dan prasarana kerja yang ada disekitar pagawai yang sedang melakukan pekerjaan yang dapat memengaruhi pelaksanaan pekerjaan. Lingkungan kerja ini meliputi tempat bekerja, fasilitas dana alat bantu pekerjaan, kebersihan, pencahayaan, ketenangan, termasuk juga hubungan kerja antara orang-orang yang ada di tempat tersebut.

Oleh karena itu, lingkungan kerja dapat memberikan dampak semangat kerja bagi pegawai. Dapat disimpulkan bahwa semakin pihak sekolah memperhatikan lingkungan kerja pegawai, maka semakin tinggi pula kinerja yang diberikan oleh pegawai, 
dikarenakan pegawai merasa semangat ketika mereka diperhatikan lingkungan kerjanya

\section{Pengaruh Budaya Organisasi}

Terhadap Kinerja Pegawai SMP IT Permata Hati Banjarnegara

Hasil penelitian menunjukan bahwa terdapat pengaruh positif dan tidak signifikan budaya organisasi terhadap kinerja pegawai. Oleh karena itu dapat dipahami bahwa variabel budaya organisasi tidak berpengaruh positif dan tidak signifikan terhadap kinerja pegawai. Selanjutnya penelitian ini juga membuktikan bahwa jika variabel budaya organisasi ditingkatkan maka budaya organisasi tidak berpengaruh terhadap kinerja pegawai SMP IT Permata hati Banjarnegara.

Hasil penelitian ini sejalan dengan penelitian yang dilakukan oleh Nur Faridah (2019) yang menyatakan bahwa Budaya Organisasi tidak mempengaruhi kinerja karyawan sektor publik. Akan tetapi hasil ini bertolak belakang dengan penelitian yang dilakukan oleh Pamungkas (2013) dimana Budaya organisasi berpengaruh secara positif dan signifikan terhadap kinerja karyawan di STMIK AUB Surakarta. Luthans (2011) menyatakan bahwa budaya organisasi adalah pola pemikiran dasar yang diajarkan kepada personel baru sebagai cara untuk merasakan, berfikir, dan bertindak secara benar dari hari ke hari.

Dengan adanya penelitian ini membuktikan bahwa budaya organisasi mempunyai pengaruh dan tidak signifikan terhadap kinerja pegawai SMP IT Permata Hati Banjarnegara.

\section{Pengaruh Beban Kerja Terhadap} Kinerja Pegawai SMP IT Permata Hati Banjarnegara

Hasil penelitian menunjukan bahwa terdapat pengaruh negatif dan signifikan beban kerja terhadap kinerja pegawai. Hal ini sesuai dengan hipotesis ketiga $\left(\mathrm{H}_{3}\right)$ yang dirumuskan dimana beban kerja berpengaruh terhadap kinerja pegawai. Beban kerja yang berlebihan akan berdampak pada rendahnya kinerja pegawai.

Hasil ini sejalan dengan penelitian Adhar Ariffudin dan Muh Ryman Napirah (2015) mengemukakan penelitian dengan judul hubungan Beban kerja terhadap kinerja karyawan di RSUD (Palu) ini. Hasil penelitian menunjukkan bahwa ada hubungan dengan kinerja perawat di ruang rawat inap RSUD Undata Palu. Mangkuprawira (2013) menyatakan beban kerja karyawan sudah ditentukan oleh perusahaan menggunakan standar 
kerja menurut jenis pekerjaannya. Beban kerja sangat penting bagi sebuah perusahaan/instansi. Dengan pemberian beban kerja yang efektif perusahaan dapat mengetahui sejauh mana karyawannya dapat diberikan beban kerja yang maksimal dan sejauh mana pengaruhnya terhadap kinerja perusahaan itu sendiri.

Dengan adanya penelitian ini membuktikan bahwa beban kerja mempunyai pengaruh negatif dan signifikan terhadap kinerja pegawai SMP IT Permata Hati Banjarnegara

Pengaruh Lingkungan Kerja, Budaya Organisasi dan Beban Kerja Terhadap Kinerja Pegawai SMP IT Permata Hati Banjarnegara

Hasil penelitian menunjukan bahwa lingkungan kerja, budaya organisasi dan beban kerja berpengaruh positif dan signifikan terhadap kinerja pegawai SMP IT permata Hati Banjar negara. Hal ini sesuai dengan hipotesis keempat $\left(\mathrm{H}_{4}\right)$ yang dirumuskan dimana lingkungan kerja, budaya organisasi dan beban kerja berpengaruh terhadap kinerja pegawai

Hasil penelitian ini sejalan dengan hasil penelitian yang dilakukan oleh Baiquni dan Prihatini (2016) bahwa nilai koefisien determinasi budaya organisasi dan lingkungan kerja terhadap kinerja karyawan pada Harian Pagi Tribun Jateng sebesar $31,3 \%$ artinya variabel kinerja karyawan dapat dijelaskan oleh variabel budaya organisasi dan lingkungan kerja, sedangkan sisanya ada faktor lain yang mempengaruhi kinerja karyawan seperti keselamatan kerja, kepuasan kerja, stress kerja maupun kompensasi. Hasil penelitian ini mendukung teori yang dikemukakan Menurut Siagian (2002:124) bahwa kinerja dipengaruhi oleh beberapa faktor diantaranya budaya organisasi dan lingkungan kerja yang terdapat pada perusahaan tersebut.

\section{KESIMPULAN}

Dari pembahasan yang telah diuraikan, maka dapat disimpulkan sebagai berikut :

1. Lingkungan kerja berpengaruh positif dan signifikan terhadap kinerja pegawai SMP IT Permata Hati Banjarnegara. Hal ini bearti lingkungan kerja yang membuat pegawai nyaman dan aman dapat meningkatkan produktivitas pegawai dalam mengerjakan tugas yang ada.

2. Budaya Organisasi tidak berpengaruh positif dan signifikan terhadap kinerja pegawai SMP IT 
Permata Hati Banjarnegara. Hal ini bearti penanaman nilai-nilai organisasi belum dapat diterima dengan baik oleh para pegawai sehingga tidak memberikan pengaruh yang baik terhadap kinerja para pegawai.

3. Beban kerja berpengaruh negatif dan signifikan terhadap kinerja pegawai di SMP IT Permata Hati Banjarnegara. Hal ini bearti beban kerja yang terlalu tinggi dapat menghambat kinerja para pegawai. Sehingga berdampak pada rendahnya produktivitas para pegawai dalam menyelesaikan tugas yang ada.

4. Lingkungan kerja, budaya organisasi dan beban kerja secara simultan memberikan pengaruh signifikan terhadap kinerja pegawai. Hal ini bearti pihak sekolah harus memperhatikan kenyamanan dan kemanan lingkungan kerja para pegawai, penanaman budaya organisasi serta pertimbangan terhadap beban kerja pegawai yang proporsional.

\section{SARAN}

Berdasarkan kesimpulan yang telah dilakukan maka saran yang dapat diberikan dalam penelitian ini yaitu:
1. Bagi pihak yayasan agar dapat terus menjaga lingkungan kerja yang terdiri dari keamanan dan kenyaman para pegawai baik ruang kerja maupun suasana kerja sehingga kinerja pegawai dapat terus terjaga.

2. Bagi pihak yayasan agar dapat mempertimbangkan atau mengkaji ulang tugas yang diberikan sesuai peran dari masing-masing pegawai sehingga para pegawai dapat mentutaskan pekerjaan sesuai peran masing-masing

3. Bagi penelitian selanjutnya dapat melakukan penelitian terhadap kinerja pegawai dengan menggunakan variabel lainnya yang tidak digunakan dalam penelitian ini agar dapat melengkapi hasil penelitian yang telah dilakukan.

\section{DAFTAR PUSTAKA}

Adhar Ariffudin dan Muh Ryman Napirah. 2015. Hubungan Disiplin dan Beban Kerja dengan Kinerja Perawat di Ruang Rawat Inap Rumah Sakit Umum Daerah (RSUD) Undata Palu. Healthy Tadulako Journal. Vol. 1 No.1 
Agripa, T. Sitepu. 2013. Beban Kerja dan

Motivasi Pengaruhnya Terhadap

Kinerja Karyawan Pada PT. Bank

Tabungan Negara TBK Cabang

Manado. Jurnal EMBA. Vol.1 No.4

1123-1133

Anggit, A. 2014. Pengaruh Stres Kerja dan Beban Kerja Terhadap Kinerja Karyawan PDAM Surabaya. Jurnal Ilmu dan Riset Manajemen. Vol. 3 No. 7.

Arianto, D.A.N. 2013. Pengaruh Kedisiplinan, Lingkungan Kerja dan Budaya Kerja Terhadap Kinerja Tenaga Pengajar. Jurnal Economica. Vol. 9. No. 2. hlm 191200

Baiquni dan Prihatini. 2016. Pengaruh Budaya Organisasi dan Lingkungan Kerja Terhadap Kinerja Karyawan Pada PT. Warta Media Nusantara Tribun Jateng. JIAB Vol. 5 No. 3

Bastian, Indra. 2013. Akuntansi Sektor Publik Suatu Pengantar Edisi Ketiga. Jakarta: Erlangga

Dessler, Gary. 2015. Manajemen Sumber Daya Manusia. Jakarta: Salemba Empat.

Faridah, N., Anisatun. 2019. Pengaruh Motivasi Kerja, Gaya
Kepemimpinan, Budaya Organisasi dan Locus of Control Terhadap Kinerja Karyawan Sektor Publik. Yogyakarta: Universitas Islam Indonesia

Hakim, A. 2015. Effect of Organizational Culture, Organizational Commitment to Performance: Study in Hospital of District South Konawe of Southeast Sulawesi. The International Journal of Engineering and Science (IJES), Vol.4, No.5, pp.33-41.

Luthans, Fred. 2011. Perilaku Organisasi (terj.), Edisi 10. Yogyakarta: Andi Offset

Mangkuprawira. 2013. Manajemen Sumber Daya Manusia Strategik. Jakarta: Penerbit Ghalia.

Muhammad, Adolfina, dan Lumintang. 2016. Pengaruh Lingkungan Kerja, Kompensasi dan Beban Kerja Terhadap Kinerja Karyawan Pada Dinas Pendapatan Daerah Kota Manado. Jurnal EMBA. Vol. 4 No.1 hlm 045-055.

Munandar. 2001. Psikologi Industry dan Organisasi. Universitas Indonesia, Jakarta. 
.Pratama, Himawan Aditya. 2019. Pengaruh Lingkungan Kerja Fisik dan Non Fisik Terhadap Kebosanan Kerja Karyawan di Akademi Maritim Yogyakarta (AMY). Jurnal Majalah Ilmiah Bahari Jogja. Vol. 17 No.2 Juli 2019 Hal $23-83$

Robbins, Stephen P. 2012. Perilaku Organisasi. Alih Bahasa oleh: Benyamin Molan. Cetakan I. Indonesia: PT.Indeks.

Sedarmayanti. 2011. Membangun Dan Mengembangkan Kepemimpinan Serta Meningkatkan Kinerja Untuk Meraih Keberhasilan. Bandung: Refika Aditama.

Siagian, S.P. 2002. Kiat Meningkatkan Produktivitas Kerja. Jakarta: Rineka Cipta.

Sugiyono. 2012. Metode Penelitian Kombinsasi. Bandung: Alfabeta.

Sugiyono. 2013. Metode Penelitian Pendidikan Pendekatan Kuantitatif, Kualitatif, dan $R \& D$. Bandung: Alfabeta.

Sutrisno, Edy. 2010. Manajemen Sumber Daya Manusia. Jakarta: Kencana.
Syauta, J H. et al. 2012. The Influence of Organizational Culture, Organizational Commitment to Job Satisfaction and Employee Performance (Study at Municipal Waterworks of Jayapura, Papua Indonesia). International Journal of Business and Management Invention. Vol.1, No.1, pp.69-76.

Trisnaningsih. 2007. Independensi Auditor dan Komitmen Organisasi sebagai Mediasi Pengaruh Pemahaman Good Governance, Gaya Kepemempinan dan Budaya Organisasi Terhadap Kinerja Auditor. Simposium Nasional Akuntansi X.

Yasa dan Utama .2014. pengaruh kompensasi dan lingkungan kerja terhadap kepuasan kerja dan kinerja karyawan pada Karma Jibaran. $e$ Jurnal Manajemen. Vol. 3. No.3 